\title{
Wear Behavior of TiAlN and CrAlN Coatings Deposited by TRD Process on AISI D2 Steel
}

\author{
B. KILINC ${ }^{a}$, O. CEGIL ${ }^{b}, \mathrm{~S} . \mathrm{SEN}^{c}$ AND U. SEN \\ ${ }^{a}$ Department of Metallurgical and Materials Engineering, Institute of Arts and Sciences, Sakarya University \\ Esentepe Campus, 54187 Sakarya, Turkey \\ ${ }^{b}$ Korfez Technical and Industrial Vocational High School, Department of Metal Technology \\ 41780, Korfez/Kocaeli, Turkey \\ ${ }^{c}$ Department of Metallurgical and Materials Engineering, Engineering Faculty, Sakarya University \\ Esentepe Campus, 54187 Sakarya, Turkey \\ The wear properties of uncoated, chromium aluminum nitride (CrAlN) and titanium aluminum nitride (TiAlN) \\ coated AISI D2 steel were investigated and compared using ball-on-disc method at $0.3 \mathrm{~m} / \mathrm{s}$ sliding speed and under \\ the loads of $2.5 \mathrm{~N}, 5 \mathrm{~N}$, and $10 \mathrm{~N}$ against $\mathrm{Si}_{3} \mathrm{~N}_{4}$ ball as a counter material. Steel samples were nitrided at $575^{\circ} \mathrm{C}$ for \\ $8 \mathrm{~h}$ in the first step of the coating process, and then titanium aluminum nitride coating and chromium aluminum \\ nitride were performed by thermoreactive deposition (TRD) process at $1000^{\circ} \mathrm{C}$ for $2 \mathrm{~h}$. Coated samples were \\ characterized by X-ray diffraction analysis, scanning electron microscopy, microhardness, and ball on disk wear \\ tests. The results of friction coefficient and wear rate of the tested materials showed that the TiAlN coating \\ presents the lowest results.
}

DOI: $10.12693 /$ APhysPolA.125.362

PACS: 81.15.-z, 46.55.+d, 81.65.Lp

\section{Introduction}

Wear is defined as damage to a solid surface, generally involving progressive loss of material, due to relative motion between contacting surfaces $[1,2]$. Over the last two decades the market for wear reducing and friction lowering coatings has grown tremendously. The development of wear reducing coatings has started with tool coating [3]. Nitride based hard compound coatings found increasing applications for nearly every demand. High hardness, excellent wear and corrosion resistance enable them to improve tool life greatly. Among them, TiN and $\mathrm{CrN}$ are respectively the first and the second most frequently employed coatings [4]. The ternary coating system of titanium-aluminium-based nitride is attractive due to its significant enhancement of oxidation resistance and mechanical properties with respect to TiN [5]. TiAlN made tool coating popular because of their excellent performance.

Chromium based coatings are a promising choice for components. These coatings combine good wear properties and a high corrosion resistance. The ternary system chromium aluminum nitride is of high interest for tool and component applications [3, 4, 6-8]. Titanium aluminium nitride coatings have been applied to tools, dies, and many mechanical parts to increase their lifetime and performance owing to their attractive properties such as high hardness, good thermal stability and oxidation resistance, good wear and chemical stability $[9,10]$. CrAlN and TiAlN coatings have been deposited by different physical vapour deposition (PVD) techniques: magnetron sputtering, arc ion plating, cathodic arc evaporation and pulsed laser deposition $[11,12]$.

TRD process is a method of coating steels with a hard, wear resistant layer of carbides, nitrides, or carbonitrides. In the TRD process, the carbon and nitrogen in the steel substrate diffuse into a deposited layer with a carbide forming or nitride forming element such as vanadium, niobium, tantalum, chromium, molybdenum, or tungsten. The diffusion carbon or nitrogen reacts with carbides and nitride forming elements in the deposited coating so as to form dense and metallurgically bonded carbide or nitride coating at the substrate surface [9]. The purpose of the present study is to investigate the tribological properties of untreated and thermo-chemically coated TiAlN and CrAlN surfaces by ball-on-disc method.

\section{Experimental procedure}

In the experimental studies, the AISI D2 steel is used, of which composition is $1.54 \% \mathrm{C}, 0.28 \% \mathrm{Si}, 0.29 \% \mathrm{Mn}$, $0.023 \%$ P, $0.005 \%$ S, $11.3 \%$ Cr, $0.74 \%$ Mo, $0.77 \%$ Ni, $0.74 \% \mathrm{~V}$, and iron (balance). Test pieces of AISI D2 steel were sectioned the dimensions of $20 \mathrm{~mm}$ in diameter and $5 \mathrm{~mm}$ in thickness and prepared metallographically. The pre-nitriding treatment was carried out in a nitrogen and ammonia atmosphere at $575^{\circ} \mathrm{C}$ for $8 \mathrm{~h}$. Then chromium aluminium nitride $(\mathrm{CrAlN})$ and titanium aluminium nitride (TiAlN) coatings were performed on the pre-nitrided steel samples by the thermoreactive deposition technique in a powder mixture consisting of ferro-chromium (for CrAlN), ferro-titanium (for TiAlN), aluminum (by $5 \mathrm{wt} \%$ for $\mathrm{CrAlN}$ and $7 \mathrm{wt} \%$ for TiAlN), ammonium chloride and alumina at $1000^{\circ} \mathrm{C}$ for $2 \mathrm{~h}$. The morphological details and layer thickness measurements of samples were carried out using optical microscopy and scanning electron microscopy. X-ray diffraction (XRD) analysis was performed on the coated sample surfaces. The hardness of uncoated steel, CrAlN and TiAlN coating layers were measured with $5 \mathrm{~g}$ load.

Ball-on-disk arrangement was used for the friction and wear tests. The silicon nitride $\left(\mathrm{Si}_{3} \mathrm{~N}_{4}\right)$ ball, $10 \mathrm{~mm}$ in di- 
ameter, was used as a counter material during the wear test. The wear test parameters are given in Table I. Wear rate was measured primarily by volumetric (volume loss) means. Worn volume (v) of the disk materials was calculated using profilemeter and the equation of the wear rate is given in Eq. (1) [13]:

$$
\mathrm{WR}=v / S,
$$

where $v(\pi D A)$ is the volumetric loss $\left(\mathrm{mm}^{3}\right)$ of wear track, $D$ is the diameter of the wear track $(\mathrm{mm}), A$ is the area $\left(\mathrm{mm}^{2}\right)$ of the cross-section of the wear track which is calculated using profilemeter and $S$ is the sliding distance $(\mathrm{m})$. Specific wear rate $(k)$ was calculated using Eq. (2) [14], where $P$ is the applied load (N). Worn tracks of counter disks and wear scars of worn balls were examined by optical microscope and measured with optical micrometer

$$
k=(v / S) P .
$$

Wear tests parameters.

TABLE I

\begin{tabular}{c|c}
\hline \hline Test parameters & Value \\
\hline wear samples & uncoated, CrAlN and \\
TiAlN coated steel \\
applied load $[\mathrm{N}]$ & $2.5,5,10$ \\
sliding speed $\left[\mathrm{m} \mathrm{s}{ }^{-1}\right]$ & 0.3 \\
environment & air \\
humidity [\%] & $65 \pm 5$ \\
temperature $\left[{ }^{\circ} \mathrm{C}\right]$ & $21 \pm 3$ \\
sliding distance $[\mathrm{m}]$ & 200 \\
test ball & $\mathrm{Si}_{3} \mathrm{~N}_{4}$ \\
test ball diameter $[\mathrm{mm}]$ & 9,5
\end{tabular}

\section{Results and discussion}

Figure 1 shows the cross-sectional optical and SEM micrographs of the CrAlN and TiAlN coated AISI D2 tool steels. CrAlN coating layer was dense and exhibits laminar microstructure with a well-defined coating/substrate interface. TiAlN coating layer was of compact, smooth and porosity-free morphology and homogeneous the entire surface of steel samples. The thickness of the CrAlN and TiAlN layers is examined $11.8 \pm 1.3 \mu \mathrm{m}$ and $7.89 \pm 0.34 \mu \mathrm{m}$, respectively. The $\mathrm{CrAlN}$ and TiAlN coatings exhibit higher hardness [15] of $2067 \pm 160 \mathrm{HV}_{0.005}$ and $2251 \pm 255 \mathrm{HV}_{0.005}$ than that of uncoated steel $(550 \pm 14 \mathrm{HV})$, respectively. XRD patterns of the CrAlN and TiAlN coated AISI D2 steels of which phases are $\mathrm{Cr}_{2} \mathrm{~N},(\mathrm{Cr}, \mathrm{Fe})_{2} \mathrm{~N}_{1-x}, \mathrm{AlN}, \mathrm{Fe}_{2} \mathrm{~N}$ and $\mathrm{TiN}, \mathrm{AlTi}_{3} \mathrm{~N}$ and $\mathrm{Ti}_{3} \mathrm{Al}_{2} \mathrm{~N}_{2}$, respectively.

The values of the friction coefficient and wear rate of CrAlN, TiAlN and uncoated steels against the silicon nitride ball are given in Table II. Figure 2a presents the variation of friction coefficients of the uncoated and CrAlN and TiAlN coated steels tested under the loads of $5 \mathrm{~N}$, and Fig. 2b presents the specific wear rate for uncoated, CrAlN and TiAlN coated steels. It is clear from Fig. 2a that the friction coefficient of tested materials increases with sliding distance up to $20 \mathrm{~m}$, approximately and so gets the steady state behavior. Over this distance, there is no any significant change in coefficient of friction values. As shown from Table II, the uncoated AISI
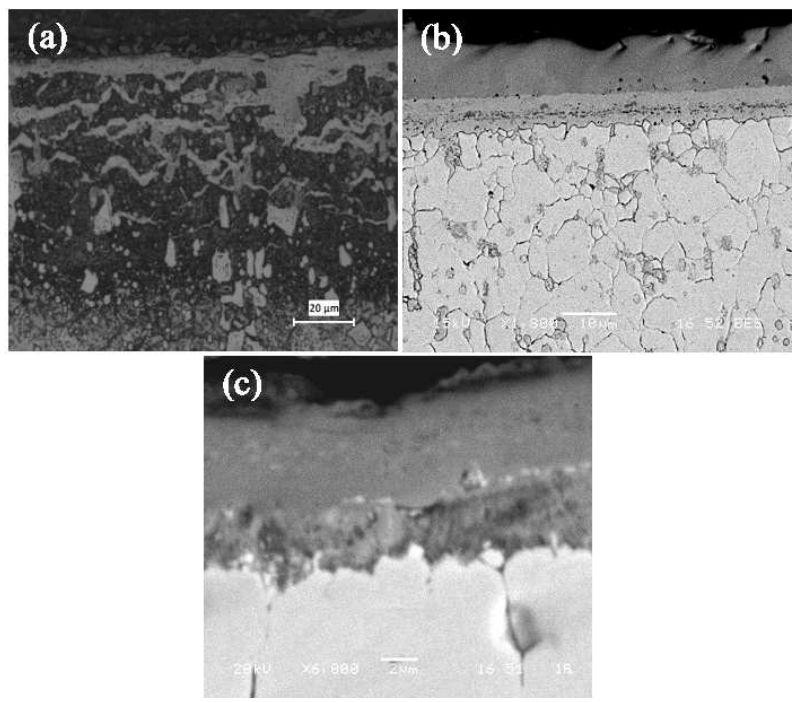

Fig. 1. The optical and SEM micrographs of (a) nitrided, (b) CrAlN coated, and (c) TiAlN coated AISI D2 steels.

D2 steel presents the highest friction coefficient, while the TiAlN presents the lowest friction coefficient. Average coefficient of friction values of uncoated, CrAlN and TiAlN coated steels are $0.883 \pm 0.032,0.301 \pm 0.154$ and $0.158 \pm 0.021$, respectively. According to the uncoated AISI D2 steel, friction coefficient of the CrAlN and TiAlN coating are $65.9 \%$ and $82.1 \%$ decreased. In general, friction coefficient of the uncoated steel and CrAlN and TiAlN coatings are not changed effectively with applied load. The results showed that the TiAlN has the lowest friction coefficient value among the tested materials $[4,10,16-18]$.

The values of the friction coefficient and wear TABLE II rate of CrAlN, TiAlN and uncoated steels.

\begin{tabular}{c|c|c|c|c|c}
\hline \hline Sample & $\begin{array}{c}\text { Sliding } \\
\text { speed } \\
{[\mathrm{m} / \mathrm{s}]}\end{array}$ & $\begin{array}{c}\text { Load } \\
{[\mathrm{N}]}\end{array}$ & $\begin{array}{c}\text { Coefficient } \\
\text { of friction }\end{array}$ & $\begin{array}{c}\text { Wear rate } \\
\times 10^{-5} \\
{\left[\mathrm{~mm}^{3} / \mathrm{m}\right]}\end{array}$ & $\begin{array}{c}\text { Specific } \\
\text { wear rate } \\
\times 10^{-5} \\
{\left[\mathrm{~mm}^{3} / \mathrm{Nm}\right]}\end{array}$ \\
\hline uncoated & 0.3 & $\begin{array}{c}5.5 \\
10\end{array}$ & 0.862 & 21.3 & \\
\hline CrAlN & 0.3 & 5 & 0.867 & 24.2 & 30.5 \\
coated & & 10 & 0.214 & 83.5 & 11.6 \\
\hline TiAlN & 0.3 & 5 & 0.479 & 108.5 & \\
coated & & 10 & 0.163 & 29.5 & 2.0 \\
& & & & &
\end{tabular}

As shown from Table II, wear rate of the uncoated, CrAlN and TiAlN coated steels are changing between $2.13 \times 10^{-4} \mathrm{~mm}^{3} / \mathrm{m}-2.4 \times 10 \times 10^{-3} \mathrm{~mm}^{3} / \mathrm{m}$, $9.0 \times 10^{-5} \mathrm{~mm}^{3} / \mathrm{m}-1.08 \times 10 \times 10^{-3} \mathrm{~mm}^{3} / \mathrm{m}$ and $1.31 \times 10^{-4} \mathrm{~mm}^{3} / \mathrm{m}-2.95 \times 10 \times 10^{-4} \mathrm{~mm}^{3} / \mathrm{m}$, respectively. In general, increase in load value caused the increase of wear rate of all the tested materials [9]. It is clear from the results that the $10 \mathrm{~N}$ load caused severe wear for uncoated and CrAlN coated steels, whereas TiAlN was to withstand to severe conditions of $10 \mathrm{~N}$ wear load. Specific wear rates of the CrAIN and TiAlN coated 
steels are $62 \%$ and $93.4 \%$ lower than that of the uncoated steel. The results of friction coefficient and wear rate of the tested materials showed that the TiAlN coating presents the lowest results.

Figure 3 shows the worn tracks formed on uncoated CrAlN and TiAlN coated AISI D2 steels tested under the loads of $0.3 \mathrm{~m} / \mathrm{s}$. Microstructures of worn tracks against silicon nitride ball showed that the worn parts of the coated steels surfaces are shown as white zone, while the worn zone are grayish on the wear track. As shown from the figure, the wear track formed on the coated steels are formed on the top surface of the coating layer, whereas TiAlN coated steel against the balls has a good wear resistance. Wear tracks formed on the uncoated disk materials exhibit abrasive wear. Wear tracks formed on the CrAlN and TiAlN coated include adhesive spots. Similarly, dimensions of worn scars formed on the ball materials are getting larger with increase in load. $\mathrm{W}$ is realized deeper on the uncoated steel. In addition to this, wear track formed on the TiAlN coated steel has the lowest dimension. It was shown that the wear mechanisms formed on the coated steels are adhesive wear.

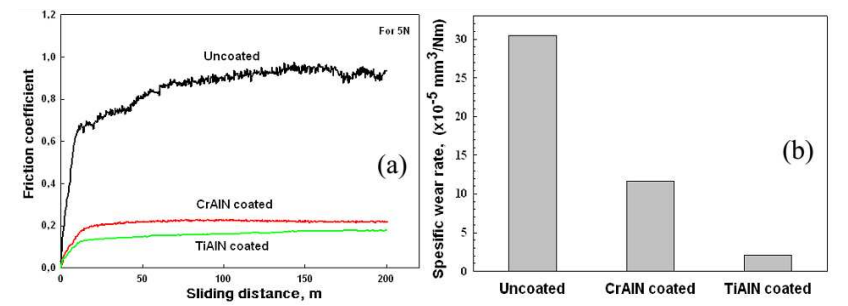

Fig. 2. (a) The friction coefficient, (b) specific wear rate of uncoated, CrAlN and TiAlN coated AISI D2 steels against the silicon nitride ball.
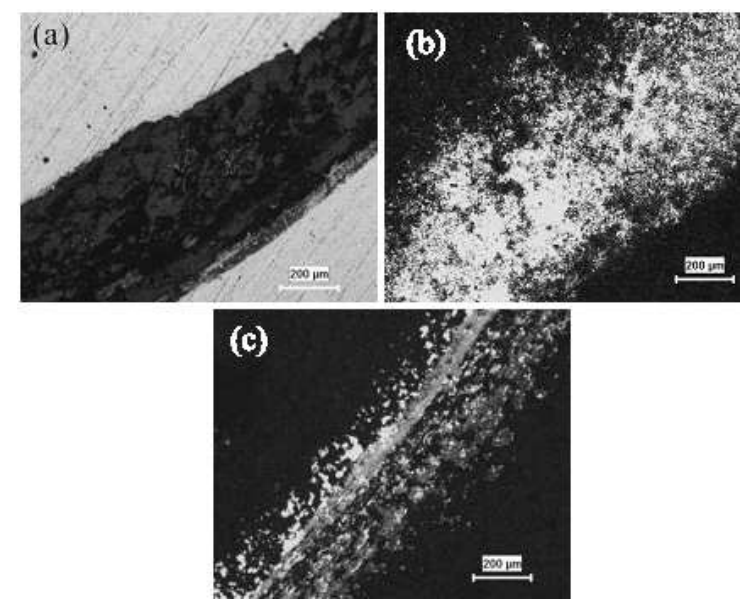

Fig. 3. Optical micrographs of wear track of (a) uncoated, (b) CrAlN coated, and (c) TiAlN coated AISI D2 steels.

\section{Conclusions}

The results of this work demonstrate that well adhered (diffusion controlled) TiAlN coating can have very beneficial effect on the tribological behavior compared to
CrAlN coated and uncoated steel surfaces. It is concluded that:

- TiAlN layer coated on the steel substrate are compact, smooth, porosity-free and homogeneous. CrAlN and coating layer was dense and exhibits laminar microstructure with a well-defined coating/substrate interface.

- The CrAlN and TiAlN coatings exhibit higher hardness of $2067 \pm 160 \mathrm{HV}_{0.005}$ and $2251 \pm 255 \mathrm{HV}_{0.005}$ than that of uncoated steel $(550 \pm 14 \mathrm{HV})$, respectively.

- The phases formed in the TiAlN and CrAlN coated layers are $\mathrm{TiN}, \mathrm{AlTi}_{3} \mathrm{~N}, \mathrm{Ti}_{3} \mathrm{Al}_{2} \mathrm{~N}_{2}$, and $\mathrm{Cr}_{2} \mathrm{~N}$, $(\mathrm{Cr}, \mathrm{Fe})_{2} \mathrm{~N}_{1-x}, \mathrm{AlN}, \mathrm{Fe}_{2} \mathrm{~N}$, respectively.

- The results of friction coefficient and wear rate of the tested materials showed that the TiAlN coating presents the lowest results.

\section{References}

[1] X.Z. Ding, C.T. Bui, X.T. Zeng, Surf. Coat. Technol. 203, 680 (2008).

[2] H. Unal, U. Sen, A. Mimaroglu, Mater. Des. 26, 705 (2005).

[3] K. Bobzin, E. Lugscheider, R. Nickel, N. Bagcivan, A. Kramer, Wear 263, 1274 (2007).

[4] A. Liu, J. Deng, H. Cui, Y. Chen, J. Zhao, Int. J. Refract. Met. Hard Mater. 31, 82 (2012).

[5] B. Gakovi, M. Trtica, B. Radak, S. Petrovi, P. Panjan, M. Cekada, T. Desai, D. Batani, J. Opt. A 11, 1 (2009).

[6] H. Scheerer, H. Hoche, E. Broszeit, B. Schramm, E. Abele, C. Berger, Surf. Coat. Technol. 200, 203 (2005).

[7] M. Uchida, N. Nihira, A. Mitsuo, K. Toyoda, K. Kubota, T. Aizawa, Surf. Coat. Technol. 177-178, 627 (2004).

[8] X.Z. Ding, X.T. Zeng, SIMTech Tech. Rep. 6, 1 (2005).

[9] U. Sen, Mater. Des. 26, 167 (2005).

[10] O. Cegil, B. Kllınc, U. Sen, S. Sen, in: IMMC'16 Metallurgy $\&$ Materials Congress, Istanbul (Turkey), Eds.: A.F. Dericioglu, K. Kazmanli, S. Timur, C. Durucan, H. Savaş, UCTEA Chamber Of Metallurgical Engineers, Istanbul 2012, p. 453.

[11] B. Kilinc, S. Sen, S. Demirkiran, U. Şen, Acta Phys. Pol. A 123, 268 (2013).

[12] B. Kilinc, S. Sen, U. Sen, Acta Phys. Pol. A 123, 271 (2013).

[13] C. Martini, G. Palombarini, G. Poli, D. Prandstraller, Wear 256, 608 (2004).

[14] H.S. Benabdallah, R.J. Boness, J. Mater. Sci. 34, 4995 (1999).

[15] V. Chawla, J. Mater. Sci. Eng. A 3, 22 (2013).

[16] V.H. Derflinger, A. Schutze, M. Ante, Surf. Coat. Technol. 200, 4693 (2006).

[17] H. Kim, C.Y. Kim, D.W. Kim, I.S. Lee, G.H. Lee, J.C. Park, S.J. Lee, K.Y. Lee, Biomed. Mater. 044108, 5 (2010).

[18] K.N. Andersen, E.J. Bienk, K.O. Schweitz, H. Reitz, J. Chevallier, P. Kringhøj, J. Bøttiger, Surf. Coat. Technol. 123, 219 (2000). 